\title{
Sosyal Güvenlik Dergisi'nde Yayımlanan Makalelerin Bibliyometrik Analizi
}

\section{Bibliometric Analysis of the Articles Published in Journal of Social Security}

\author{
Elif KIRDAR* \\ (iD) 0000-0003-2094-0297
}

\author{
Abdurrahman BENLi'** \\ (iD) 0000-0002-0756-7339
}

Sosyal Güvenlik Dergisi / Journal of Social Security

Cilt: 10 Say1: 1 Y1l: 2020 /Volume: 10 Issue: 1 Year: 2020

Sayfa Aralığı: 197-216 Pages: 197-216

DOI: 10.32331/ sgd.753112

\section{ÖZ}

Bu makalenin amacı, uluslararası, hakemli ve bilimsel bir dergi olan Sosyal Güvenlik Dergisi'nde 2011-2019 yılları arasında yayımlanmış makalelerin bibliyometrik özellikleri açısından incelenmesidir. Sosyal güvenlik alanına katkıda bulunulması için yılda iki kez yayımlanan dergiden ele alınan yıllar kapsamında 138 makaleye ulaşılmıştır. Ulaşılan makaleler bibliyometrik özellikleri açısından incelenmiştir. Yapılan incelemeler sonucunda; çok yazarlılık durumuna bakıldığında daha çok bireysel çalışma tercih edilmiştir. Yazarların unvan durumu açısından değerlendirildiğinde en çok Prof. Dr. ve Dr. Öğretim Üyesi unvanlarıyla makale yayımlandığı görülmüştür. En fazla yayım yapan ilk üç kurum Hacettepe Üniversitesi, Ankara Üniversitesi ve Gazi Üniversitesi olmak üzere toplam 73 kurum bu çalışmaya katkı sağlamıştır. Makalelerin \% 84'ü üniversiteler tarafından \% 16'sı üniversite dışı kurumlar tarafindan yazılmıştır. Kaynak kullanımına bakıldığında, \% 53 oranında yerli kaynak, \% 47 oranında yabancı kaynak kullanılmıştır. Kaynak türü olarak sırasıyla dergi, kitap ve diğer kaynaklar tercih edilmiştir. Atıf durumu incelendiğinde, Sosyal Güvenlik Dergisi'ne toplamda 830 atıf yapılmış, öz atıf sayısının 49 olduğu görülmüştür. Makalelerin ortalama sayfa sayısı 34'tür. Makalelerin dilleri dikkate alındığında \% 92'si Türkçe, \% 8’i İngilizce yayımlanmıştır.

Anahtar Sözcükler: Sosyal Güvenlik Dergisi, bibliyometrik analiz, sosyal güvenlik

\section{ABSTRACT}

The purpose of this article is to examine the articles published between 2011-2019 in terms of bibliometric features in the Journal of Social Security, which is an international, peer-reviewed and scientific journal. In order to contribute to the field of social security, 138 articles from the journal,which is published twice a year, have been reached within the scope of the years discussed and the articles reached have been examined in terms of their bibliometric features. As a result of the examinations; considering the multi-authorship status, more individual work is preferred. When we look at the title of the authors, more articles have been published with the titles of Prof. Dr. and Dr. Lecturer, A total of 70 institutions, including the top three publishing institutions, Hacettepe University, Ankara University and Gazi University, have contributed to this study. 84 percent of the articles were written by universities and 16 percent by non-university institutions. Considering the use of resources, 53 percent domestic resources and 47 percent foreign resources have been used. As the source type, journals, books and other sources have been preferred respectively. When the citation status is examined, a total of 830 citations have been made to the Social Security Journal, and the number of self citations is 49 . The average number of pages of the articles is 34 . Considering the languages of the articles, 92 percent are published in Turkish and 8 percent in English.

Keywords: Journal of Social Security, bibliometric analysis, social security

Önerilen atıf şekli: Kırdar, E. ve Benli, A. (2020). Sosyal Güvenlik Dergisi’nde Yayımlanan Makalelerin Bibliyometrik Analizi. Sosyal Güvenlik Dergisi (Journal of Social Security). 10(1). 197-216.

Kabul Tarihi/Accepted: 16/06/2020

\footnotetext{
* Doktora Öğrencisi, Sakarya Üniversitesi, Siyasal Bilgiler Fakültesi, Çalışma Ekonomisi ve Endüstri İlişkileri Bölümü, elif.kodan1@ogr.sakarya.edu.tr

** Doç. Dr., Sakarya Üniversitesi, Siyasal Bilgiler Fakültesi, Çalışma Ekonomisi ve Endüstri İlişkileri Bölümü, abenli@sakarya.edu.tr
} 


\section{GíRíş}

Bibliyometri kavramını ilk kez kullanan Pritchard kavramı, matematik ve istatistiksel yöntemler kullanılarak kitap ve dergi gibi yayınların analiz edilmesi şeklinde tanımlamıştır. Bilgi bilimi alanında hızlı kabul göreceğini ve yazılı iletişim süreçlerini ölçmek isteyen çalışmalar tarafından kullanılacağını belirtmiştir (Pritchard, 1969: 348-349). Bibliyometrik çalışmalar, farklı alanlarda bilim adamları tarafından yapılan işin nitelik ve niceliğini araştırmak için diğer bilim insanlarına olanak sağlar (Jacobs, 2001). Bilimin elde edilen sonuçlarla tasvir edilebildiği bibliyometrik yaklaşımlar, bilimsel araştırmanın özünün bilgi üretimi olduğu ve bilimsel literatürün bu bilginin kurucu tezahürü olduğu fikrine dayanmaktadır (Okubo, 1997: 8). Bibliyometrik teknikler zamanla gelişmiştir. Ülke, kurum ve yazar tarafından atıfta bulunulan makalelerin sayılması, yayınlanmış çalışmanın bilimsel topluluk üzerindeki etkisini ölçmek için atıfların sayılması, alıntıların sayılması gibi çeşitli kriterler eklenerek gelişimini sürdürmektedir. Kriterlerin artması sonucunda bibliyometrik analizler daha etkili ve ayrıntılı sonuçlar vermektedir (Okubo, 1997: 9).

$\mathrm{Bu}$ bağlamda, bibliometrik analiz kavramı altında yürütülen farklı bir takım analiz çalışmaları da yeni kavramlarla ifade edilmektedir. Eğer belirli türde bir bilginin ölçülmesi hedefleniyorsa ki bu bilginin tanınmış birisi tarafından bir tür değer yargısı oluşturmak için kullanıldığı değerlendirilmektedir. Bu durumda bibliometrik analizin türü 'bilimsel ölçüm analizi-scientometrics' olmaktadır. Geniş anlamda bilimsel ve teknolojik bilginin üretilmesi ve yayılması ile ilgili olarak ortaya konan modellerin nicel özelliklerini kapsamaktadır. Bilimin ne olduğu konusunda öncelikli birtakım varsayımlar ve gerçek bilimsel başarının nasıl algılanması gerektiği dikkate alınarak bilimsel ölçüm analizi bilim adamlarının, bilimsel çalışma gruplarının, kurumların ve ülkelerin bilginin gelişimine yaptıkları katkıyı nicel ve karşılaştırmalı olarak analiz etmektedir. Yukarıda belirtildiği üzere yayımlanmış çalışmalar analize konu olabilecek çok sayıdaki birimden bir tanesini oluşturmaktadır. Makalelerin yanı sıra; işgücü, üretim, tesisler, ekonomik ve finansal girdiler ve çıktılar da değerlendirmeye konu olmaktadır. Hem bilimsel ölçüm hem de bibliometrik analiz ile ilgili araştırmalar, yayınlar yoluyla yapılmakta, bilimsel ve teknik literatüre uygulanmaktadır. Bu nedenle her iki alan birbirleri ile önemli ölçüde çakışmaktadır (Bellis, 2009: 3).

Ayrıca, bibliometrik analiz kavramı altında gelişen bir diğer kavram günümüzde ortaya konan bilgisayar ve dijital ağlar devriminin şafağında herhangi bir bilginin nicel özelliklerini değerlendiren 'infometrik analiz' kavramıdır. Bugün bilgi birçok alanda anahtar role sahip bulunmaktadır ve gerçekten de bilim insanları bilgisayarları ve bilgi ağlarını yoğun bir şekilde kullanmaktadır. Bilim insanları teknolojinin sunduğu bu imkanları bir araç ve ölçeği ve karmaşıklığı ne olursa olsun bilginin yorumlanmasında bir araç olarak kullanmaktadır (Bellis, 2009: 4).

\section{I- LITERATÜR TARAMASI}

Bibliyometrik analiz tekniği, yerli ve yabancı literatürde birçok farklı alanda kullanılmıştır. Özellikle son yıllarda bu alana gösterilen ilgi alanda yayımlanan çalışmalara da yansımıştır. Web of Science'te yapılan araştırmada Social Sciences Citation Index kapsamında bibliometric kelimesinin yer aldığı 1980-2012 tarihleri arasında 2,072 yayım olduğu sonucuna ulaşılmıştır (Şakar ve Cerit, 2013: 40). Aşağıda bilimin farklı alanlarında yapılan yerli ve yabancı çalışmalara örnekler verilmiştir. 
Nitel araştırma tekniği kullanılarak çeşitli alanlarda yapılan pek çok çalışma bulunmaktadır. Özen, 2001 yılında yaptığı çalışmada 1996-1998 yılları arasında düzenlenen Ulusal Yönetim ve Organizasyon Kongrelerinde sunulan bildirileri, yöntemsel tekdüzelik ve yetersizlik boyutları kapsamında inceleyerek betimlemiştir. Yazının genelinde yaşanan yöntem sorunu, araştırma tasarımı aşamasında hangi yaklaşımın egemen olduğu, hangi konulara ilgi gösterildiği gibi sorulara cevap aramıştır. Üsdiken ve Erçek 2009 yılında yaptıkları çalışmada 1943 - 1948 yıllarında yayımlanmış işletme konularında uygulama dünyasına yönelik makalelerin yer aldığı Türkiye'deki ilk dergi olan İşletme - İşletme Ekonomisi ve Organizasyon Mecmuası'nı incelemişlerdir. Yazarlar incelemelerinde dergideki yazıların dayanağı, yazarların başvurduğu söylemler, dergide hangi kavramların üzerinde yoğunlaşıldığı gibi sorulara cevap aramışlardır. Yine aynı yılda Üsdiken ve Wasti yaptıkları çalışmada, 1970 - 1999 yılları arasında belirledikleri kriterlere göre seçilen dergilerdeki makaleleri analiz ederek bilgi üretim modellerini ortaya çıkarmayı amaçlamışlardır.

Liu ve diğerleri 2005 yılında yaptıkları çalışmada 1900-2009 yılları arasında Bilimsel Atıf Dizini'ne (SCI) dayanarak biyoçeşitlilik araştırmaların bibliyometrik analizini yapmışlardır. Çalışmanın bilimsel çıktılardaki ve akademik işbirliklerindeki örüntüleri ortaya çıkarmakta olduğunu ve biyoçeşitlilikte küresel araştırma eğilimlerini ortaya çıkarmanın farklı ve yeni bir yolu olduğunu savunmuşlardır (Liu vd., 2005: 807).

Müller ve arkadaşları 2015 yılında yaptıkları çalışmada 1980 - 2015 yılları arasında Web of Science Core Collection'daki fiziksel aktivite ve yaşlanma konusu ile ilgili çeşitli kriterlerden sonra yayımlanan 9.935 makalenin bibliyometrik özelliklerini incelemişlerdir. Konu ile ilgili makalelerin tamamının 2007 yılından sonra yazıldığı sonucuyla birlikte makalelerin hangi kategoride yazıldığı, yayım dili, atıfta bulunulan yayınlar gibi birçok kriter belirleyerek bibliyometrik analizi gerçekleştirmişlerdir.

Hussain ve diğerleri çalışmalarında Elektronik Kütüphane Dergisi'nin bibliyometrik analizini yapmışlardır. Bu dergide 2000 - 2010 yılları arasında yayımlanan 578 makalenin yıllara göre dağılımı, makalelerin kategori bazında sınıflandırılması, üretken yazarlar gibi birçok özelliğini incelemişlerdir.

Ho, 2013 yılında yayımlanan makalesinde Web of Science'ın SSCI veri tabanına dayanarak 1856 - 2011 yılları arasında sosyal hizmet alanında yazılan 50 ve üzeri atıf alan klasik makalelerin bibliyometrik özelliklerini incelemiştir. Bu kriterler dahilinde 721 makaleye ulaşan yazar, yazarlar, ülkeler ve kurumlar gibi çeşitli gösterge kullanarak bibliyometrik analizi gerçekleştirmiştir.

Ruhanen ve arkadaşları 1987 - 2012 yılları arasında sürdürülebilir turizm alanındaki etki faktörü en yüksek olan dört dergideki 492 makalenin bibliyometrik özelliklerini incelemişlerdir. Dergi adı, yayım tarihi, yazarların adları ve çalıştıkları kurumlar gibi çeşitli özellikler excel programında analiz edilmiştir.

Fejes ve Nylander, Scopus veritabanında 2005 - 2012 yılları arasında yetişkinlerin eğitimi ve öğrenimi alanında hem ülke hem de kıta açısından üç farklı coğrafi konumu temsil eden üç dergide yayımlanan makalelerin bibliyometrik özelliklerini incelemişlerdir.

Krishnamoorthy ve arkadaşları 2009 yılında yaptıkları çalışmada 1995 - 2004 yılları arasında Medline Cd Rom veritabanında yer alan diyabet alanındaki çalışmalar yazar, başlık, yayım türü, dil, yıl, katkıda bulunanların kurumları, yayımlandığı ülke, kaynak gibi kriterlerle analiz etmişlerdir. 
Al ve Tonta 2004 yılında yaptıkları çalışmada 1974 - 2002 yılları arasında Hacettepe Üniversitesi Kütüphanecilik Bölümü'nde 100 adet lisansüstü tezinin bibliyometrik analizini gerçekleştirmişlerdir. Tezlerdeki atıf sayıları, ortalama sayfa uzunluğu, atıf yapılan kaynak türleri, en çok atıf yapılan dergi türleri gibi birçok kritere göre analiz yapılmıştır.

Al ve Coştur 2007 yılında yazdıkları makalede Türk Psikoloji Dergisi’nde 1995-2005 yılları arasında yayımlanan 118 makaleyi bibliyometrik özellikleri açısından incelemişlerdir. Yazarlar; yayımlanan makalelerin psikolojinin hangi alt dallarına odaklandığı, çok yazarlılık durumu, makale yazarlarının hangi kurumlarda görev yaptığı, en çok atıf yapılan kaynak türünün ne olduğu, en sık atıf yapılan dergiler hangileridir gibi kriterlerle bibliyometrik analizi gerçekleştirmişlerdir.

Birinci 2008 yılında yaptığ Chemistry'de 1995-2007 yılları arasında yer alan 861 makaleyi bibliyometrik özellikleri bakımından incelemiştir. Yazar araştırmasında dergideki en verimli yazarlar, yazarlar arasındaki ilişki durumu, çok yazarlılık durumu, dergiye makale gönderen yazarların kurumları, atıf yapılan kaynak türleri gibi sorulara cevap aramıştır.

Özel ve Kozak, 2012 yılında turizm pazarlaması alanında Türkçe makale yayımlayan hakemli dergilerdeki makalelerin bibliyometrik özelliklerini ve makalelerde yer alan atıfları incelemişlerdir. Yazarlar, araştırmaları sonucu 286 makaleye, bu makalelerde de toplam 8436 atıf yapıldığına ulaşmışlardır. Bu bilgiler doğrultusunda makalelerin hangi alanda daha çok yayımlanması, en çok makale yayımlayan dergilerin hangileri olduğu, atıfların hangi atıf yasasına uyduğu, makalelerin çok yazarlılık durumu gibi birçok özelliğini incelemişlerdir.

Şakar ve Cerit, 2013 yılındaki çalışmalarında Web of Science'ın SSCI veri tabanı kapsamında 1980- 2012 yılları arasında Türkiye pazarlama alanındaki makalelerin bibliyometrik analizini yapmışlardır. Yazarların amacı, uluslararası indekslerde Türkiye'nin pazarlama yazınına katkısını belirlemek ve yaptıkları nitel bir araştırmayla uluslararası indekslerde yer alan Türkiye adresli pazarlama yerini akademisyenlerin görüşleriyle değerlendirmektir.

Hotamışlı ve Erem 2014 yılında yazdıkları makalede 2005-2013 yılları arasında Muhasebe ve Finansman Dergisi'nde yayımlanan 562 makalenin bibliyometrik özelliklerini incelemişlerdir. Makalelerde hangi konulara ağırlık verildiği, en fazla yayım yapan kurum, atıf yapılan kaynakların dağılımı, dergiye atıf sayısı ve öz atıf sayısı gibi çeşitli kriterlerle bibliyometrik analizi gerçekleştirmişlerdir.

Cansun ve Arık, 2019 yılında Türkiye adresli siyaset bilimleri üzerine ilk bibliyometrik çalışmayı yapmışlardır. 1900 - 2016 yılları arasında Web of Science'ın Social Science Citation Index ve Arts \& Humanities Citation Index veri tabanlarında siyaset bilimi yayınlarını incelemişlerdir. Yayımların tarihleri, türleri, hangi dilde olduğu, atıf ve kaynak sayıları gibi çeşitli kriter kullanarak analizi gerçekleştirmişlerdir.

Çokişler, 2019 yılında Uluslararası İlişkiler Dergisi’ni (2004-2017) bibliyometrik analiz tekniği ile incelemiş ve bu amaçla derginin 14 yıllık yayın hayatı, 4-5-5 yıllık üç ara döneme ayırarak yayımlanan 56 sayıda yer alan toplam 316 makale ve 319 yazar hakkında bibliyometrik verileri derlemiştir.

Belirli bir alanın gelişim düzeyini belirlemede kullanılan bibliyometrik çalışmalara ilgi özellikle 2000'li yıllar itibariyle oldukça artmıştır. Bilimin birçok alanında kullanılabilen bu yöntem akademisyenler tarafından çalıştıkları alanlara uygulanmıştır. 
Sosyal Güvenlik Dergisi’nde Yayımlanan Makalelerin Bibliyometrik Analizi

Tablo 1. Sosyal Güvenlik, Sosyal Politika ve Endüstri İlişkileri Disiplinleri Alanlarındaki Bazı Bibliyometrik Çalışmalar

\begin{tabular}{|c|c|c|c|c|}
\hline $\begin{array}{l}\text { Yazar } \\
\text { İsimleri }\end{array}$ & Çalışmanın Adı & $\begin{array}{l}\text { Çalışmanın } \\
\text { Yayımlandığı } \\
\text { Yer }\end{array}$ & Çalışmanın Konusu & $\begin{array}{c}\text { Yayım } \\
\text { Yılı }\end{array}$ \\
\hline $\begin{array}{l}\text { Martinez ve } \\
\text { diğerleri }\end{array}$ & $\begin{array}{l}\text { Meksika Sosyal Güvenlik } \\
\text { Enstitüsü Personeli } \\
\text { Tarafindan Yapılan } \\
\text { Yayınların Bibliyometrik } \\
\text { Analizi }\end{array}$ & $\begin{array}{l}\text { Gaceta Medica } \\
\text { de Mexico }\end{array}$ & $\begin{array}{l}\text { Ulaşılan } 300 \text { makalenin araştırma } \\
\text { türü, çalışma alanı ve konusu, ilk } \\
\text { yazarın ana faaliyetleri ve derginin } \\
\text { etki faktörü özellikleri } \\
\text { incelenmiştir. }\end{array}$ & 2000 \\
\hline $\begin{array}{l}\text { McMillan } \\
\text { ve Casey }\end{array}$ & $\begin{array}{l}\text { Araştırma notu: İngiliz } \\
\text { Endüstri İlişkileri } \\
\text { Dergisi’nin Görünmez } \\
\text { Kolejlerini Belirleme: } \\
\text { Bibliyometrik Analiz ve } \\
\text { Sosyal Ağ Yaklaşımı }\end{array}$ & $\begin{array}{l}\text { British Journal } \\
\text { of Industrial } \\
\text { Relations }\end{array}$ & $\begin{array}{l}\text { British Journal of Industrial } \\
\text { Relations Dergisi, } 1986 \text { - } 2005 \\
\text { yılları arası dönemlere ayrılarak } \\
\text { makalelerin hangi literatüre } \\
\text { dayandığı belirtilip, olası bulguların } \\
\text { açıklamaları ve sonuçları } \\
\text { tartışılmıştır. }\end{array}$ & 2007 \\
\hline $\begin{array}{l}\text { McMillan } \\
\text { ve Casey }\end{array}$ & $\begin{array}{l}\text { Endüstri ve Çalışma } \\
\text { İlişkileri İncelemesinin } \\
\text { Görünmez Kolejlerinin } \\
\text { Tanımlanması: Bir } \\
\text { Bibliyometrik Yaklaşım }\end{array}$ & $\begin{array}{l}\text { Industrial and } \\
\text { Labor Relations } \\
\text { Review (ILRR) }\end{array}$ & $\begin{array}{l}\text { Endüstri ilişkileri alanında en önde } \\
\text { gelen dergilerinden biri olan } \\
\text { Industrial and Labor Relations } \\
\text { Review, 1974 - } 2006 \text { yılları üç } \\
\text { döneme ayrılarak bibliyometrik } \\
\text { teknikler kullanılarak analiz } \\
\text { edilmiştir. }\end{array}$ & 2008 \\
\hline $\begin{array}{l}\text { McMillan } \\
\text { ve Casey }\end{array}$ & $\begin{array}{l}\text { Endüstri İlişkilerinde } \\
\text { Paradigma Değişimi: } \\
\text { Bibliyometrik Analiz ve } \\
\text { Sosyal Ağ Yaklaşımı }\end{array}$ & $\begin{array}{l}\text { Advances in } \\
\text { Industrial and } \\
\text { Labor Relations }\end{array}$ & $\begin{array}{l}\text { Bu makalede, son } 40 \text { yılda en iyi } \\
\text { endüstri ilişkileri dergilerinde } \\
\text { yayımlanan bilimsel çalışmalar, } \\
\text { bibliyometrik analiz tekniği ve } \\
\text { sosyal ağ yaklaşımı kullanılarak } \\
\text { incelenmiştir. }\end{array}$ & 2010 \\
\hline $\begin{array}{l}\text { Manzano } \\
\text { ve } \\
\text { Agugliaro }\end{array}$ & $\begin{array}{l}\text { Çalışma İlişkileri Scopus } \\
\text { tarafından Endekslenen } \\
\text { Dünya Çapında Bilimsel } \\
\text { Değerlendirme }\end{array}$ & Publications & $\begin{array}{l}\text { Bu makalede } 1970 \text { - } 2016 \text { yılları } \\
\text { arasında Scopus Elsevier veritabanı } \\
\text { kapsamında çalışma ilişkilerinde } \\
\text { uzmanlaşmış literatürün dünya } \\
\text { çapında katkıları bibliyometrik } \\
\text { analiz tekniğiyle incelenmiştir. }\end{array}$ & 2017 \\
\hline $\begin{array}{l}\text { Doucouliagos } \\
\text { ve diğerleri }\end{array}$ & $\begin{array}{l}\text { Sendikaların } \mathrm{Ne} \\
\text { Yaptıklarının } \\
\text { Bibliyometrik Analizi }\end{array}$ & $\begin{array}{l}\text { The Economics } \\
\text { of Trade } \\
\text { Unions: A } \\
\text { Study of a } \\
\text { Research Field } \\
\text { and Its Findings } \\
\text { (Kitap Bölümü) }\end{array}$ & $\begin{array}{l}\text { Bu çalışmada } 1984 \text { - } 2014 \text { yılları } \\
\text { arasında Web Of Science } \\
\text { kapsamında Çalışma ve Endüstri } \\
\text { İlişkileri alanında yayımlanan 1,480 } \\
\text { bilgiye ulaşılıp bu bilgiler } \\
\text { bibliyometrik analiz tekniğiyle } \\
\text { incelenmiştir. }\end{array}$ & 2017 \\
\hline $\begin{array}{l}\text { McMillan } \\
\text { ve Casey }\end{array}$ & $\begin{array}{l}\text { Çalışanların Sesi ve } \\
\text { Sessizliği: Literatürün } \\
\text { Bibliyometrik Analizi }\end{array}$ & $\begin{array}{l}\text { International } \\
\text { Journal of } \\
\text { Bibliometrics in } \\
\text { Business and } \\
\text { Management } \\
\text { (Kitap Bölümü) } \\
\end{array}$ & $\begin{array}{l}\text { Bu çalışmada Web of Science'da } \\
\text { Clarivate Analytics indeksinde } \\
\text { çalışanların ses ve sessizliği ile ilgili } \\
376 \text { yazı bibliyometrik analiz } \\
\text { tekniği kullanılarak incelenmiştir. }\end{array}$ & 2019 \\
\hline Özgüler & $\begin{array}{l}\text { Sosyal Siyaset } \\
\text { Konferansları Dergisi ve } \\
\text { Uluslararası Çalışma } \\
\text { Örgütü (ILO) }\end{array}$ & $\begin{array}{l}\text { Sosyal Siyaset } \\
\text { Konferansları } \\
\text { Dergisi }\end{array}$ & $\begin{array}{l}\text { Bu makalede, } 2019 \text { yılında } 100 . \\
\text { yılına ulaşmış olan ILO ile } 71 . \\
\text { yılına ulaşmış Sosyal Siyaset } \\
\text { Konferansları Dergisi nitel } \\
\text { araştırma yöntemiyle analiz } \\
\text { edilmiştir. }\end{array}$ & 2019 \\
\hline $\begin{array}{l}\text { García ve } \\
\text { diğerleri }\end{array}$ & $\begin{array}{l}\text { Kamu Emeklilik } \\
\text { Sistemleri: Bilimsel } \\
\text { Dergilerde Akademik } \\
\text { Yayımların Bibliyometrik } \\
\text { Çalışması }\end{array}$ & $\begin{array}{l}\text { Economic } \\
\text { Challenges of } \\
\text { Pension } \\
\text { Systems (Kitap } \\
\text { Bölümü) }\end{array}$ & $\begin{array}{l}\text { Bu kitap bölümünde, Web of Scince } \\
\text { ve Scopus veritabanlarında } \\
\text { indekslenmiş belgelerin } \\
\text { karşılaştırmalı bibliyometrik } \\
\text { çalışması yoluyla Kamu Emeklilik } \\
\text { sistemleri üzerindeki bilimsel } \\
\text { üretimin durumunu sunmaktadır. }\end{array}$ & 2020 \\
\hline
\end{tabular}


Bu bağlamda, Sosyal Güvenlik, Sosyal Politika ve Endüstri İlişkileri disiplinleri alanlarında çeşitli dergilerde ve editörlü kitap çalışmalarında bibliyometrik analizlerin yapıldığı bazı araştırmalar bulunmaktadır ${ }^{1}$.

Tablo 1 bu durumu açıkça göstermektedir. Tabloya göre, ilk olarak Martinez ve diğerleri tarafından Gaceta Medica de Mexico'da 2000 yılında sosyal güvenlik alanında bir çalışma yapılmıştır. 2007 yılında ise McMillan ve Casey tarafından İngiliz Endüstri İlişkileri Dergisi'nin Görünmez Kolejlerini Belirleme: Bibliyometrik Analiz ve Sosyal A ğ Yaklaşımı adlı çalışması ile British Journal of Industrial Relations'da farklı dönemlerdeki bulgular açıklanmaya çalışılmıştır.

Aynı yazarlar tarafından 2008 yılında Industrial and Labor Relations Review (ILRR)'da 1974 - 2006 yılları arası üç döneme ayrılarak bibliyometrik teknikler kullanılarak analiz edilmiştir. Söz konusu yazarlar 2010 yılında Advances in Industrial and Labor Relations'da Endüstri İlişkilerinde Paradigma Değişimi: Bibliyometrik Analiz ve Sosyal Ağ Yaklaşımı başlıklı bir çalışma gerçekleştirmişlerdir.

Bununla birlikte, 2017 yılında Manzano ve Agugliaro tarafından 1970 - 2016 yılları arasında Scopus Elsevier veritabanı kapsamında çalışma ilişkilerinde uzmanlaşmış literatürün dünya çapında katkıları bibliyometrik analiz tekniğiyle incelenmiştir.

Doucouliagos ve diğerleri tarafından 2017 yılında The Economics of Trade Unions: A Study of a Research Field and Its Findings (Kitap Bölümü) de 1984-2014 yılları arasında Web Of Science kapsamında Çalışma ve Endüstri İlişkileri alanında yayımlanan 1,480 bilgiye ulaşılıp bu bilgiler bibliyometrik analiz tekniğiyle incelenmiştir.

Ayrıca McMillan ve Casey tarafından 2019 yılında Çalışanların Sesi ve Sessizliği: Literatürün Bibliyometrik Analizi başlıklı çalışması International Journal of Bibliometrics in Business and Management (Kitap Bölümü) olarak yayınlanmıştır. Yine Özgüler tarafından 2019 yılında Sosyal Siyaset Konferansları Dergisinde 2019 yılında 100. yılına ulaşmış olan ILO ile 71. yılına ulaşmış Sosyal Siyaset Konferansları Dergisi nitel araştırma yöntemiyle analiz edilmiştir. Bunlara ilaveten García ve diğerleri tarafından Kamu Emeklilik Sistemleri:

1 E. Valdez-Martínez, J Garduño-Espinosa, A Gómez-Delgado, J Dante Amato-Martínez, L Morales-Mori, F Blanco-Favela, O Muñoz-Hernández, (2000). Bibliometric Analysis of Publications by the Mexican Social Security Institute Staff, (Article in Spanish), Jul-Aug;136(4): 319-28.PMID: 10992632, Gac Med Mex.; McMillan, G. Steven and Casey, Debra L., (2007). "Research Note: Identifying the Invisible Colleges of the British Journal of Industrial Relations: A Bibliometric and Social Network Approach”. British Journal of Industrial Relations, Vol. 45, Issue 4, pp. 815-828, December, SSRN: https://ssrn.com/abstract=1028380 or http://dx.doi.org/10.1111/j.1467-8543.2007.00645.x; Debra L. Casey and G. Steven McMillan, (2008). "Identifying the "Invisible Colleges" of the "Industrial \& Labor Relations Review": A Bibliometric Approach, ILR Review, Vol. 62, No. 1 (Oct., 2008), pp. 126-132.; McMillan, G., \& Casey, D. L. (2010). "Paradigm Shifts in Industrial Relations: A Bibliometric and Social Network Approach”, In D. Lewin, B. E. Kaufman, \& P. Gollan (Eds.), Advances in Industrial and Labor Relations (pp. 207-255). [1840683] (Advances in Industrial and Labor Relations; Vol. 17). https://doi.org/10.1108/S07426186(2010)0000017010.; Esther Salmerón-Manzano \& Francisco Manzano-Agugliaro, (2017). "Worldwide Scientific Production Indexed by Scopus on Labour Relations," Publications, MDPI, Open Access Journal, vol. 5(4), pages 1-14, October.; Hristos Doucouliagos, Richard B. Freeman and Patrice Laroche, (2017). "A Bibliometric Analysis of What Do Unions Do?”, The Economics of Trade Unions A Study of A Research Field and Its Findings, Routhledge, London and New York.; Debra L. Casey; G. Steven McMillan, (2019). "Employee voice and silence: a bibliometric analysis of the literature”, International Journal of Bibliometrics in Business and Management (IJBBM), Vol. 1, No. 3.; Özgüler, V. (2019). "Sosyal Siyaset Konferansları Dergisi ve Uluslararası Çalışma Örgütü (ILO)”. Journal of Social Policy Conferences,(77), 235-285. DOI: 10.26650/jspc.2019.77.0013.; Jose Alvarez Garcia, Amador Duran Sanches, Marta Peris Ortiz, and Maria De La Cruz del Rio-Rama, (2020). "Public Pension Systems: Bibliometric Study of Academic Publication an Scientific Journals, Marta Peris-Ortiz, José Álvarez-García, Inmaculada Domínguez-Fabián, Pierre Devolder Economic Challenges of Pension Systems: A Sustainability and International Management Perspective, Springer London. 
Bilimsel Dergilerde Akademik Yayımların Bibliyometrik Çalışması Economic Challenges of Pension Systems (Kitap Bölümü) olarak 2020 yılında yayınlanmıştır.

Şüphesiz, dinamik ve toplumla iç içe olan sosyal güvenlik, sosyal politika ve endüstri ilişkileri ile alakalı çalışmalar (kitaplar, makaleler, tezler) bu alanlara katkı sağlayacaktır. Akademik alanda yapılan çalışmaların fazlalığı katkıyı artırırken araştırmacılar tarafından takip ve tahlil edilmesi hususunda bazı zorluklara da neden olmaktadır. Bu zorlukların giderilmesine yönelik başvurulan tekniklerden biri bibliyometrik analiz tekniğidir. Bibliyometrik çalışmalar, belirli bir alanda yapılan çalışmaların niteliğini ortaya koymakta, o alandaki eksiklere ve alanda yapılacak yeni çalışmalara 1şık tutmaktadır. Açıkçası, sosyal güvenlik, sosyal politika ve endüstri ilişskileri alanında önemli bir yeri olan Sosyal Güvenlik Dergisi’nin bibliyometrik analizi çalışmanın özgünlüğünü oluşturmaktadır.

\section{II- YÖNTEM}

Bu çalışmada 2011-2019 yılları arasında 9 yıllık dönemde yayım yapan Sosyal Güvenlik Dergisi'nde yayımlanan makalelerin nitel araştırma yöntemlerinden biri olan bibliyometrik tekniği ile analizi yapılmıştır. Sosyal Güvenlik Dergisi 2011 yılında yayım hayatına başlamıştır. 2011 yılında tek sayı olmakla birlikte senede iki kez yayımlanan uluslararası, hakemli bir bilimsel dergidir. Yayım dili Türkçe ve İngilizcedir. Dergi; Ulakbim, Ebsco Host, Econbız, Index Copernicus International, Scientific Indexing Services, Journal Factor, Asos, Sobiad ve Dergipark Akademik tarafından taranmaktadır. Dergi, "Sosyal Güvenlik Kurumunun faaliyet alanına, sosyal güvenlik, sosyal politika ve endüstri ilişkileri disiplinine katkısı olabilecek her alanda çalışmalara yer vererek, ülkemizin düşünsel birikimine katkıda bulunmak, toplumda sosyal güvenlik ve sosyal politika bilincini geliştirmek, geleceğe dönük hedef ve beklentileri ortak bir noktada buluşturmak" amacıyla yayımlanmaktadır (SGK, 2020). Sosyal Güvenlik Dergisi yayımladığı makalelerde doğrudan ya da dolaylı olarak sosyal güvenlik alanı ile ilgili konulara yer vermekle birlikte sosyal politika, çalışma ekonomisi, hukuk, işletme, iş sağlı̆̆ı ve güvenliği ile ilgili konulara da yer vermektedir. Öncelikle, Sosyal Güvenlik Dergisi hakkında genel bilgiler Tablo 2'de verilmiştir.

Tablo 2. Sosyal Güvenlik Dergisi Hakkında Genel Bilgiler

\begin{tabular}{lr}
\hline Toplam cilt sayısı & 9 \\
\hline Toplam sayı & 17 \\
\hline Türkçe makale sayısı & 127 \\
\hline İngilizce makale sayısı & 11 \\
\hline Sayı başına düşen ortalama makale sayısı & 8 \\
\hline Yayımlanan toplam makale sayfa sayısı & 3306 \\
\hline Bir makalenin ortalama sayfa sayısı & 24 \\
\hline Katkı sağlayan toplam yazar sayısı & 222 \\
\hline Toplam anahtar sözcük sayısı & 584 \\
\hline Bir makaleye düşen ortalama anahtar sözcük sayısı & 4 \\
\hline
\end{tabular}

Sosyal Güvenlik Kurumu altında 2011 yılında yayım hayatına başlayan Dergi'de 2020 yılı mayıs ayı itibariyle 1 sorumlu yazı işleri müdürü, 5 kişiden oluşan yayın kurulu, 2 editör, 1 redaktör görev almaktadır. Derginin uluslararası danışma kurulu 8 kişiden, ulusal danışma kurulu ise 44 kişiden oluşmaktadır. Bu süre içinde toplam 17 sayı 127 Türkçe, 11 İngilizce makale ile dikkati çeken bir hal almıştır. 
Bibliyometrik analizin gerçekleştirilebilmesi için belirlenen parametreler şunlardır:

$\checkmark$ Makalelerin yıllar itibariyle yayımlanma sayısı,

$\checkmark \quad$ Makalelerin yazar sayısı,

$\checkmark$ Makale yazarlarının unvanı,

$\checkmark$ Makale yazarlarının çalıştıkları kurumlar,

$\checkmark$ Makale yazarlarının bağlı olduğu fakülteler,

$\checkmark \quad 2$ ve daha fazla makalede adı geçen yazarların makale profili,

$\checkmark$ Makalelerin sayfa sayısı bilgisi,

$\checkmark$ Makalelerin yayım dili,

$\checkmark \quad$ Makalelerde kullanılan kaynak türü (yerli/yabanc1),

$\checkmark$ Makalelerde başvurulan kaynak türü (kitap, dergi, diğer kaynaklar)

$\checkmark$ Dergiye yapılan atıf sayısı ile öz atıf sayısı,

$\checkmark$ Anahtar sözcüklerde geçen en fazla kelime sayıları.

Dergide yayımlanan 138 makaleden elde edilen yukarıdaki tüm bilgiler Excel programına aktarılmış, analizler ve grafikler bu program aracılığıyla gerçekleştirilmiştir.

\section{III- BULGULAR}

Çalışmada ilk olarak Sosyal Güvenlik Dergisi'nde yayımlanan makalelerin yıllar itibariyle ilgili özellikleri incelenmiştir. Yılda 2 kez çıkarılan derginin ilk sayısı 2011 yılında, son sayısı ise 2019 yılında çıkarılmış olup, dergide toplam 138 makale yayımlanmıştır. Yayın hayatına başladığı yıl olan 2011'de dergi tek sayı çıkarılmıştır. Yıllara göre dağılım Grafik 1'de verilmiştir.

\section{Grafik 1. Makalelerin Yıllara Göre Dağılımı}

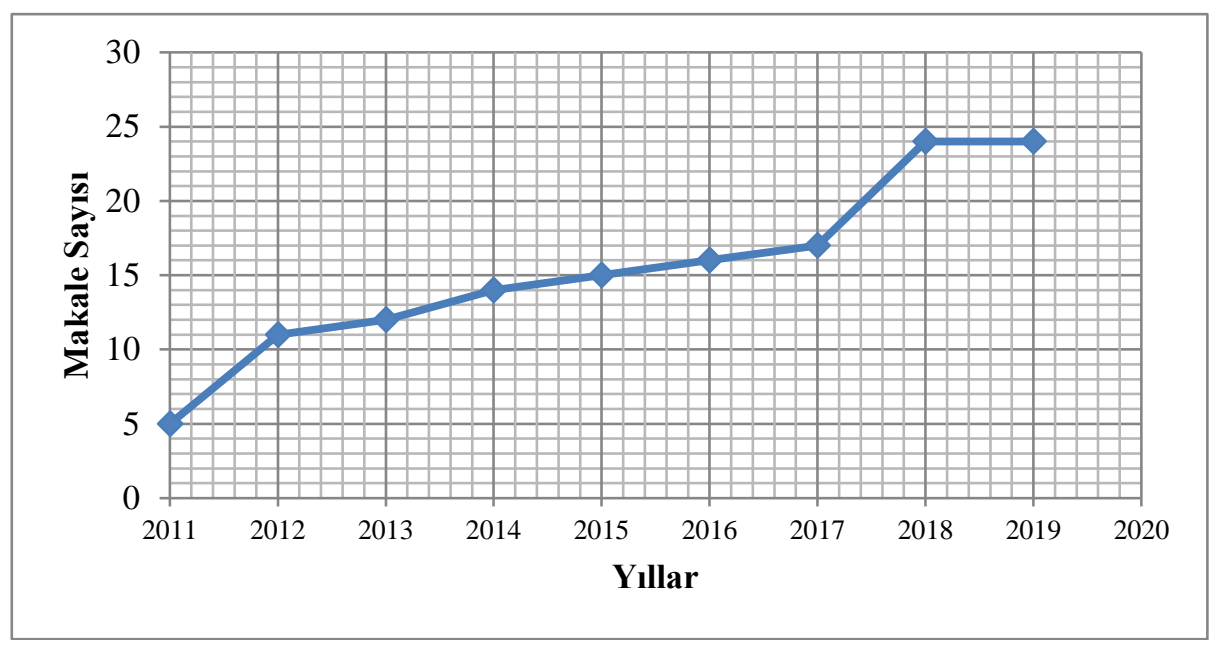

Grafik 1 incelendiğinde yıllar itibariyle yayımlanan makale sayısında artış olduğu görülmektedir. 2011 yılında tek sayı çıktığı için en az yayımlanan 5 makale bu yılda olurken, en fazla makale 24 olmak üzere 2018 ve 2019 yıllarında yayımlanmıştır.

İncelenen yıllar aralığında yayımlanan 138 makale 222 farklı araştırmacı tarafından yazılmıştır. Yayımlanan 138 makalenin yazar sayılarına bakıldığında tek yazarlı $74(\% 56,3)$ makale, iki yazarlı 46 (\% 33,3) makale, üç yazarlı 16 (\% 11,5) makale ve dört yazarlı 2 (\% $1,4)$ makale olduğu görülmüştür. Grafik 2'de yıllar itibariyle yazar sayıları verilmiştir. 
Grafik 2. Makalelerin Yazar Sayıları İtibariyle Yıllara Göre Dağılımı

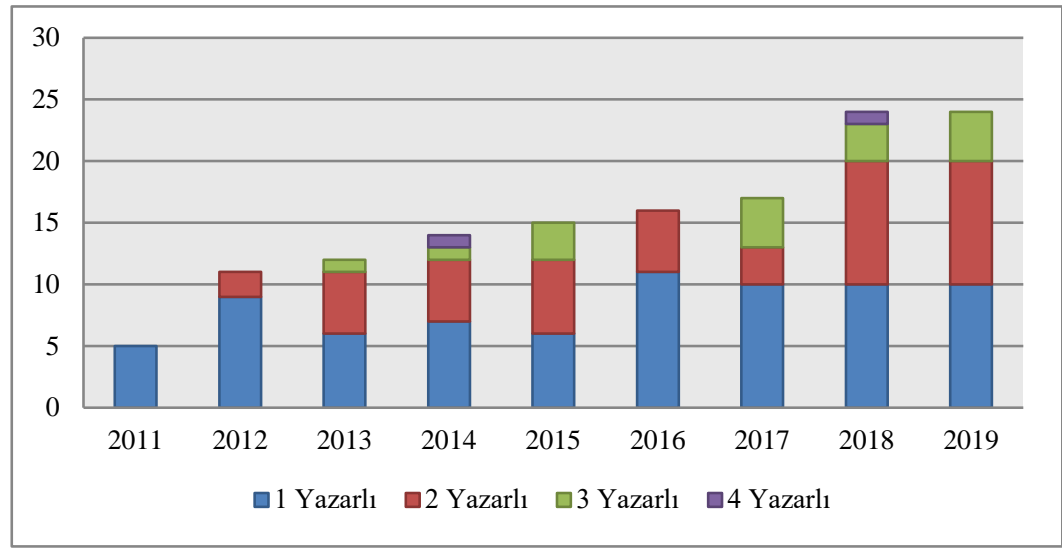

Yıllar itibariyle makalelerin yazar sayılarına bakıldığında son yıllarda 2 ve 3 yazarlı makale sayısında artış olduğu görülmektedir. Çok yazarlılık yıllar itibariyle baskın hale gelmektedir.

Öte yandan, Sosyal Güvenlik Dergisi'nde yayımlanan makalelerdeki unvanlar incelendiğinde Tablo 3 'teki durum ortaya çıkmaktadır. Prof. Dr. unvanına sahip yazarların 56 (\%25), Doç. Dr. unvanına sahip yazarların 38 (\%17), Dr. unvanına sahip yazarların 9 (\% 4), Dr. Öğretim Üyesi unvanına sahip yazarların 43 (\% 19), Araştırma Görevlisi unvanına sahip yazarların 35 (\% 16), Öğretim Görevlisi unvanına sahip yazarların 10 (\% 5), lisansüstü öğrencisi unvanına sahip yazarların 11 (\% 5), Sosyal Güvenlik Uzmanı unvanına sahip yazarların 8 (\% 4) ve diğer unvanına sahip yazarların 11 (\% 5) olduğu görülmüsştür. Diğer unvanları oluşturan 11 kişi Uzman (3), Uzman Yardımcısı (2), AB uzmanı (1), Avukat (2), İş Sağlığı ve Güvenliği Uzmanı (2), Sağlık Bakanlığı (1) unvanına sahiptir.

Tablo 3. Makalelerdeki Unvanların Yıllara Göre Dağılımı

\begin{tabular}{lcccccccccc}
\hline Unvan & $\mathbf{2 0 1 1}$ & $\mathbf{2 0 1 2}$ & $\mathbf{2 0 1 3}$ & $\mathbf{2 0 1 4}$ & $\mathbf{2 0 1 5}$ & $\mathbf{2 0 1 6}$ & $\mathbf{2 0 1 7}$ & $\mathbf{2 0 1 8}$ & $\mathbf{2 0 1 9}$ & Toplam \\
\hline Prof. Dr. & 5 & 8 & 4 & 4 & 6 & 4 & 6 & 7 & 12 & $\mathbf{5 6}(\mathbf{0 , 2 5})$ \\
\hline Doç. Dr. & - & 2 & 2 & 7 & 5 & 4 & 8 & 6 & 4 & $\mathbf{3 8}(\mathbf{0 , 1 7})$ \\
\hline Dr. & - & 1 & - & 3 & - & 1 & - & 2 & 2 & $\mathbf{9 ( 0 , 0 4 )}$ \\
\hline Dr. Öğretim Üyesi & - & - & 2 & 4 & 7 & 7 & 5 & 12 & 6 & $\mathbf{4 3 ( 0 , 1 9 )}$ \\
\hline Araştırma Görevlisi & - & 1 & 2 & 2 & 5 & 2 & 7 & 9 & 7 & $\mathbf{3 5 ( 0 , 1 6 )}$ \\
\hline Öğretim Görevlisi & - & - & 2 & - & - & - & - & 4 & 4 & $\mathbf{1 0 ( 0 , 0 5 )}$ \\
\hline & & & & & & & & & & \\
\hline Lisansüstü Öğrencisi & - & 1 & 3 & - & - & 1 & - & 1 & 5 & $\mathbf{1 1 ( 0 , 0 5 )}$ \\
\hline Sosyal Güvenlik Uzmanı & - & - & 1 & 1 & 2 & 2 & 1 & - & 1 & $\mathbf{8 ( 0 , 0 4 )}$ \\
\hline Diğgr & - & - & 3 & 3 & 1 & - & 1 & 2 & 1 & $\mathbf{1 1 ( 0 , 0 5 )}$ \\
\hline
\end{tabular}

Bununla birlikte, dergi yazarlarının temsil ettikleri kurumlarda göze çarpmaktadır. Yapılan incelemede 2011-2019 yılları arasında Sosyal Güvenlik Dergisi'nde yayımlanan makalelerin yazarlarının 70 farklı kurumda görev yaptıkları sonucuna ulaşılmıştır. Tablo 4'te iki ve daha fazla yazarın çalıştığı kurumlar verilmiştir. Tablo incelendiğinde; Hacettepe Üniversitesi 13 makale sayısı ile birinci sıradadır. Bunu Ankara Üniversitesi 12, Gazi Üniversitesi 12 ile izlerken, İstanbul, Pamukkale, Uludağ Üniversiteleri 8 makale ile dergiye en fazla makale gönderen ilk kurumlar arasında yer aldığı görülmüştür. Üniversitelerin dışında Sosyal Güvenlik Kurumu 6 makale ve Çalışma ve Sosyal Güvenlik Bakanlığı da 6 makale ile dergiye 
çalışma gönderen kurumlar arasında yer almaktadır. Sıralama yapılırken aynı kurumda yer alan araştırmacıların birlikte yaptıkları çalışmalar sadece bir kez sayılmıştır.

Tablo 4. Yazarların Çalıştıkları Kurumlara Göre Dağılımı

\begin{tabular}{lc}
\hline Kurumlar & Makale Sayıs \\
\hline Hacettepe Üniversitesi & 13 \\
\hline Ankara Üniversitesi & 12 \\
\hline Gazi Üniversitesi & 12 \\
\hline İstanbul Üniversitesi & 9 \\
\hline Pamukkale Üniversitesi & 8 \\
\hline Uludağ Üniversitesi & 8 \\
\hline Anadolu Üniversitesi & 6 \\
\hline Sosyal Güvenlik Kurumu & 6 \\
\hline Çalışma ve Sosyal Güvenlik Bakanlığ1 & 6 \\
\hline Sakarya Üniversitesi & 5 \\
\hline Karadeniz Teknik Üniversitesi & 4 \\
\hline Kocaeli Üniversitesi & 4 \\
\hline Adnan Menderes Üniversitesi & 3 \\
\hline İnönü Üniversitesi & 3 \\
\hline Çanakkale Onsekiz Mart Üniversitesi & 3 \\
\hline Ankara Hacı Bayram Veli Üniversitesi & 2 \\
\hline Celal Bayar Üniversitesi & 2 \\
\hline Çalışma ve Sosyal Güvenlik Eğitim ve Araştırma Merkezi & 2 \\
\hline İzmir Katip Çelebi Üniversitesi & 2 \\
\hline Karabük Üniversitesi & 2 \\
\hline Marmara Üniversitesi & 2 \\
\hline Muğla Sitkı Koçman Üniversitesi & 2 \\
\hline Recep Tayyip Erdoğan Üniversitesi & 2 \\
\hline Dokuz Eylül Üniversitesi & 2 \\
\hline \hline
\end{tabular}

Öte yandan, dergide makalesi yayımlanan yazarların bulundukları üniversitelerde bağlı olduğu fakülteler de incelenmiştir. Tablo 5'e bakıldığında; ilk sırada 70 makale ile $(\%$ 57,9) İktisadi ve İdari Bilimler Fakültesi yer almaktadır. İkinci sırada 12 makale ile $(\% 9,9)$ İktisat Fakültesi, 11 makale ile (\% 9,1) Hukuk Fakültesi yer almaktadır. Yazarların bağlı olduğu toplamda 11 farklı fakülteden yayımlanan makale bulunmaktadır. Farklı fakülte sayısının çok olması sosyal güvenliğin birçok bilim dalıyla iç içe olmasını kanıtlar niteliktedir.

Tablo 5. Yayımlanan Makalelerin Yazarlarının Bağlı Olduğu Fakülteler

\begin{tabular}{lcc}
\hline Fakülte Adı & Sayı & Oran \\
\hline İktisadi ve İdari Bilimler Fakültesi & 70 & 57,9 \\
\hline İktisat Fakültesi & 12 & 9,9 \\
\hline Hukuk Fakülttesi & 11 & 9,1 \\
\hline Siyasal Bilgiler Fakültesi & 8 & 6,6 \\
\hline Sağlık Bilimleri Fakültesi & 8 & 6,6 \\
\hline Meslek Yüksek Okulu & 5 & 4,1 \\
\hline İletişim Fakültesi & 3 & 2,5 \\
\hline İşletme Fakültesi & 2 & 1,7 \\
\hline Tıp Fakültesi & 1 & 0,8 \\
\hline Turizm Fakültesi & 1 & 0,8 \\
\hline Uygulamalı Bilimler Fakültesi & 1 & 0,8 \\
\hline
\end{tabular}


Bir diğer önemli olan husus ise 2011-2019 yılları arasında yayımlanan 138 makalenin yazarlarının ayrı ayrı incelenmiş olmasıdır. İki ve daha fazla makalesi yayımlanan yazarların makale profili Tablo 6'da yer almaktadır. Yayımlanan makalelerde tek yazarlı ve 2 tane makalesi bulunan yazar sayısı 7'dir. Bununla birlikte, en çok makalede adı geçen yazarlar ise; Yusuf Alper, Emel İslamoğlu, İlknur Kılkış, Erdem Cam, İsmail Ağırbaş ve Mehmet Top'tur.

Tablo 6. Ikki ve Daha Fazla Makalede Adı Geçen Yazarların Makale Profili ${ }^{*}$

\begin{tabular}{|c|c|c|c|c|}
\hline Yazar Adı & $\begin{array}{c}\text { Tek Yazarlı } \\
\text { Makale Sayısı }\end{array}$ & $\begin{array}{c}\text { 1.Yazar } \\
\text { Olunan } \\
\text { Makale Sayısı }\end{array}$ & $\begin{array}{c}\text { 2.Yazar } \\
\text { Olunan } \\
\text { Makale Sayısı }\end{array}$ & $\begin{array}{c}\text { 3.Yazar } \\
\text { Olunan } \\
\text { Makale Sayısı }\end{array}$ \\
\hline Banu METIN & 2 & - & - & - \\
\hline Kadir GÜRSOY & 2 & - & - & - \\
\hline Müslim DEMİR & 2 & - & - & - \\
\hline Nuray GÖKÇEK KARACA & 2 & - & - & - \\
\hline Tekin AKGEYİK & 2 & - & - & - \\
\hline Ufuk AYDIN & 2 & - & - & - \\
\hline Volkan IŞIK & 2 & - & - & - \\
\hline Erdem CAM & 1 & - & 2 & 2 \\
\hline Canan GÜNEŞ & 1 & 1 & - & - \\
\hline Cuma SONĞUR & 1 & 1 & - & - \\
\hline Doğa Başar SARIİPEK & 1 & - & - & 1 \\
\hline Mehmet BÖLÜKBAŞ & 1 & - & 1 & - \\
\hline Seymur AĞAZADE & 1 & 1 & - & - \\
\hline Şenay GÖKBAYRAK & 1 & 1 & - & - \\
\hline Yusuf ALPER & 1 & 1 & 2 & - \\
\hline Emel İSLAMOĞLU & - & 2 & - & 1 \\
\hline İlknur KILKIŞ & - & 2 & - & 1 \\
\hline İsmail AĞIRBAŞ & - & - & 2 & 1 \\
\hline Mehmet TOP & - & - & 3 & - \\
\hline Caner ÇAKI & - & - & 2 & - \\
\hline Handan KUMAŞ & - & - & 2 & - \\
\hline İrfan ERTUĞRUL & - & 2 & & - \\
\hline Müge ERSOY KART & - & - & 1 & 1 \\
\hline Nagihan DURUSOY ÖZTEPE & - & 2 & - & - \\
\hline Seyfettin ARTAN & - & 2 & - & - \\
\hline Sinem YILDIRIMALP & - & 1 & 1 & - \\
\hline Şenay ÜÇDOĞRUK BİRECİKLİ & - & - & 2 & - \\
\hline Türker TOPALHAN & - & 2 & - & - \\
\hline Eren ÖĞÜTOĞULLARI & - & 1 & 1 & - \\
\hline Zakir AVŞAR & - & 1 & 1 & - \\
\hline
\end{tabular}

Diğer yandan, Tablo 7'de dergide yayımlanan makalelerin sayfa sayıları dağılımına bakıldığında en çok 21-30 sayfa sayısı arasında 60 makale yazıldığı görülmektedir. 11-20 sayfa arasında 49, 31-40 sayfa arasında 24 ve 0-10 sayfa arasında 2 makale yazıldığı tespit edilmiştir. En kısa makale 9 sayfa, en uzun makale 44 sayfadır ve ortalama makale sayfa sayıs1 24'tür. 
Tablo 7. Dergide Yayımlanan Makalelerin Yıllar Itibariyle Sayfa Sayıları Dağılımı

\begin{tabular}{lcccccccccc}
\hline Sayfa Sayısı & $\mathbf{2 0 1 1}$ & $\mathbf{2 0 1 2}$ & $\mathbf{2 0 1 3}$ & $\mathbf{2 0 1 4}$ & $\mathbf{2 0 1 5}$ & $\mathbf{2 0 1 6}$ & $\mathbf{2 0 1 7}$ & $\mathbf{2 0 1 8}$ & $\mathbf{2 0 1 9}$ & Toplam \\
\hline $\begin{array}{l}\text { 0-10 sayfalı } \\
\text { makale }\end{array}$ & 0 & 0 & 2 & 0 & 0 & 0 & 0 & 0 & 0 & $\begin{array}{c}2 \\
(\% 1,4)\end{array}$ \\
\hline $\begin{array}{l}\text { 11-20 sayfalı } \\
\text { makale }\end{array}$ & 2 & 3 & 4 & 4 & 1 & 4 & 2 & 13 & 16 & $\begin{array}{c}49 \\
(\% 35,5)\end{array}$ \\
\hline $\begin{array}{l}\text { 21-30 sayfalı } \\
\text { makale }\end{array}$ & 1 & 4 & 2 & 7 & 9 & 7 & 13 & 9 & 8 & $\begin{array}{c}60 \\
(\% 43,5)\end{array}$ \\
\hline $\begin{array}{l}\text { 31-40 sayfalı } \\
\text { makale }\end{array}$ & 1 & 4 & 3 & 3 & 4 & 5 & 2 & 2 & 0 & $\begin{array}{c}24 \\
(\% 1,7)\end{array}$ \\
\hline
\end{tabular}

Sosyal Güvenlik Dergisi yayım dili Türkçe ve İngilizce'dir. Dergide yayımlanan makaleler incelendiğinde 127 makalenin Türkçe, 11 makalenin İngilizce yazıldığı görülmüştür. Grafik 3 'te bu oransal değerler verilmiştir.

Grafik 3. Makalelerde Kullanılan Dil Türü

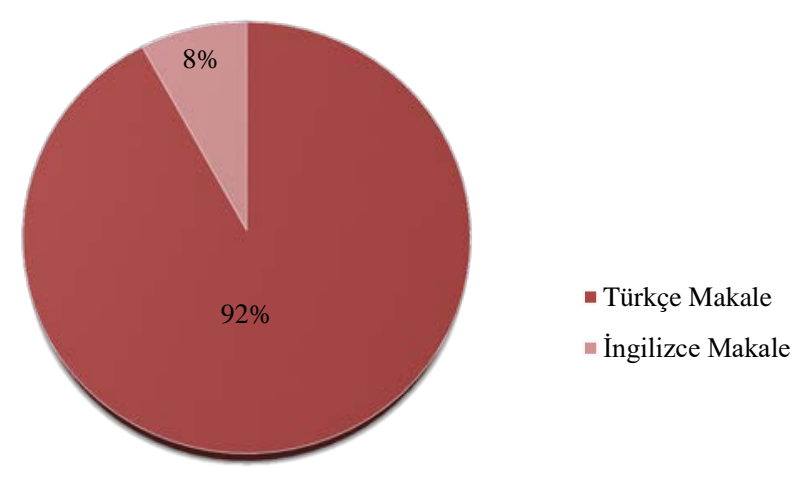

Dergide yayımlanan makalelerin kaynak türü (Grafik 4) incelendiğinde ise 2502 yerli kaynak, 2183 yabancı kaynak olmak üzere toplam 4685 kaynak kullanıldığı görülmüştür. Makale başına düşen ortalama kaynak sayısı 34'tür. Burada dikkati çeken bir durum da kaynak kullanılmayan makale sayısıdır. Hiç kaynak kullanılmayan 2 makale vardır. En çok kaynak kullanılan makale de toplam 105 kaynak bulunmaktadır.

Grafik 4. Makalelerde Yararlanılan Kaynak Türlerinin Dağılımı

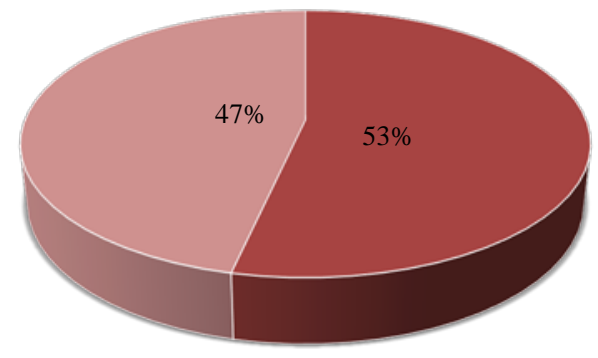

- Yerli Kaynak

- Yabancı Kaynak 
Makalelerde kullanılan kaynak türlerinin dağılımına oransal olarak bakıldığında \% 47 yabancı kaynak, \% 53 yerli kaynak kullanıldığı görülmektedir.

Dergide yayımlanan makalelerde kaynak olarak yararlanılan toplam kitap sayıs1 1256'dır. Yıllar itibariyle kaynak olarak kullanılan kitap sayıları Grafik 5’te verilmiştir.

Grafik 5. Makalelerde Kaynak Olarak Yararlanılan Kitapların Yıllar İtibariyle Dağılımı

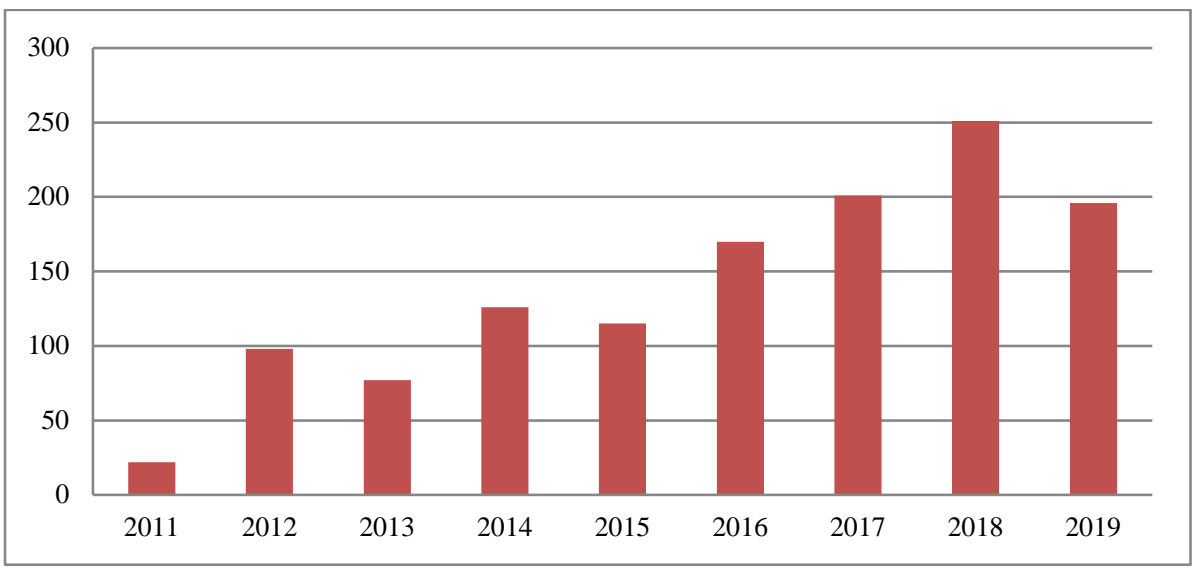

Grafik incelendiğinde 2011 yılında 22, 2012 yılında 98, 2013 yılında 77, 2014 y1lında 126, 2015 yılında 115, 2016 yılında 170, 2017 yılında 201, 2018 y1lında 251 ve son olarak 2019 yılında 196 kitabın kaynak olarak kullanıldığ görülmektedir.

Dergide incelenen dönemde makalelerin yazımında başvurulan dergi sayılarının yıllar itibariyle dağılımı da Grafik 6’te gösterilmiştir.

Grafik 6. Makalelerde Kaynak Olarak Yararlanılan Dergilerin Yıllar İtibariyle Dağıllımı

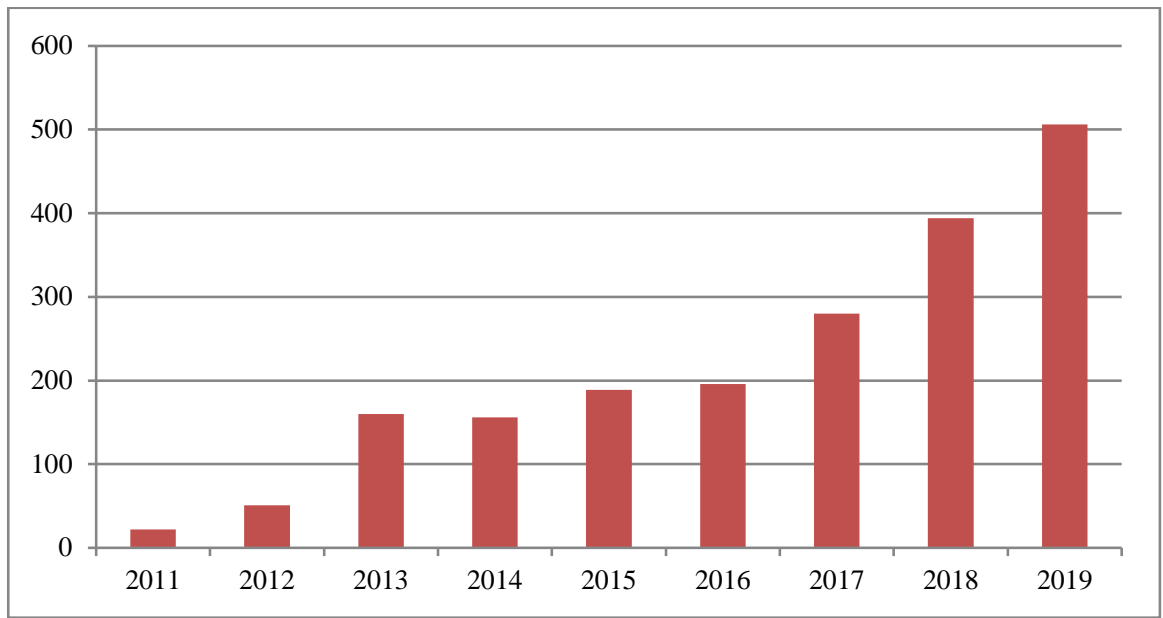

Grafik incelendiğinde dergi sayılarının 2011 yılı için 22, 2012 yılı için 51, 2013 yılı için 160, 2014 yılı için 156, 2015 yılı için 189, 2016 yılı için 196, 2017 y1lı için 280, 2018 yılı için 394, 2019 yılı için 506 olduğu görülmektedir. Kaynakçada kullanılan dergi sayısı toplam 1954’tür. 
Dergi ve kitap dışında makalelerin kaynakçasında kullanılan bildiri, elektronik kaynaklar, resmi kaynaklar, tezler, raporlar, gazeteler gibi çeşitli kaynaklara yapılan atıf sayıları Grafik 7'de verilmiştir.

Grafik 7. Makalelerde Kaynak Olarak Yararlanılan Diğer Kaynakların Yıllar İtibariyle Dă̆glımı

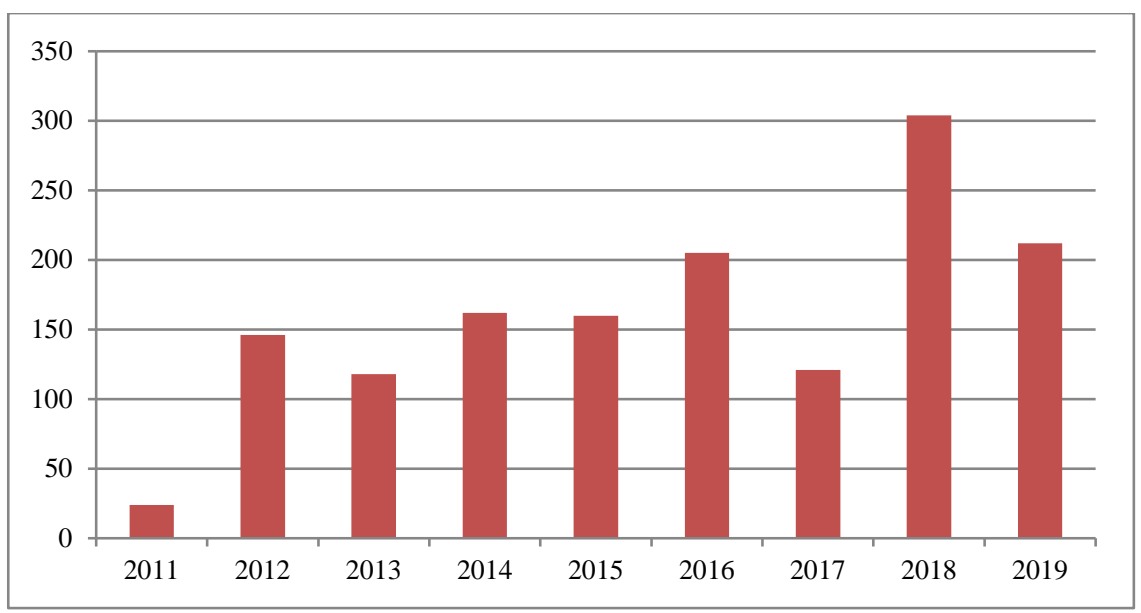

Grafik 7'ye bakıldığında; toplamda 1452 tane diğer kaynak kullanıldığ 1 görülmektedir. 2011 yılında 24, 2012 yılında 146, 2013 yılında118, 2014 yılında 162, 2015 yılında 160, 2016 yılında 205, 2017 yılında 121, 2018 yılında 304 ve 2019 yılında 212 diğer kaynak kullanılmıştır.

Sosyal Güvenlik Dergisi 2011-2019 yılları arasında yayımlanan makalelerin kaynakçasında kullanılan kitap, dergi ve diğer kaynakların dağılımı Grafik 8'de verilmiştir.

Grafik 8. Makalelerin Kaynakçasında Kullanılan Kaynak Türlerinin Dă̆ı̆lımı

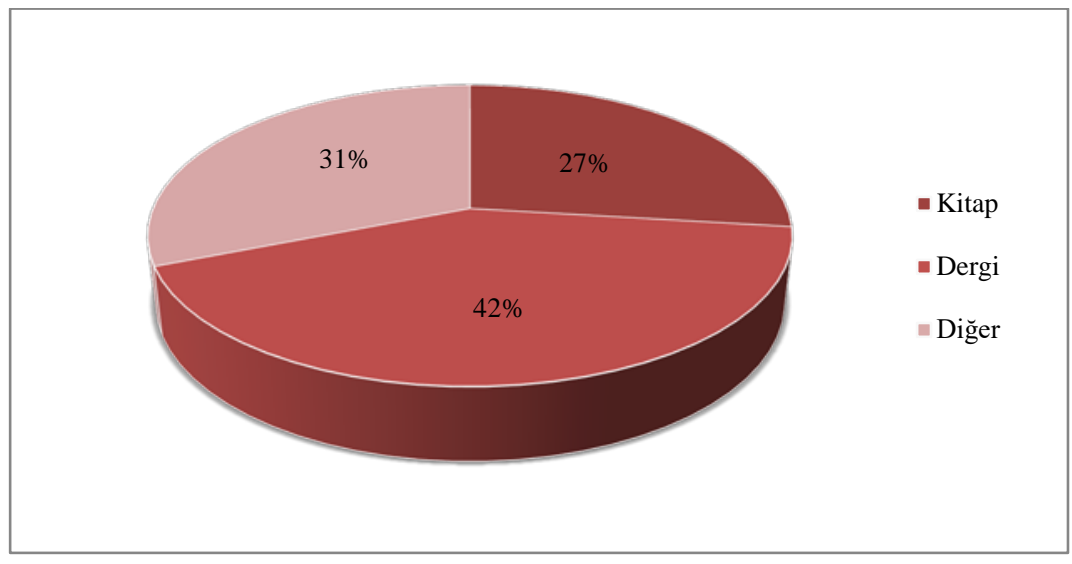

Grafik 8 incelendiğinde en çok başvurulan kaynak türü olarak \% 42 oranla dergiler öne çıkmaktadır. Diğer kaynakların oranı \% 31, kitapların oranı ise \% 27’dir.

Bilimsel olarak yayımlanan dergilerdeki başarı kriteri olarak düşünülen unsurlardan bir diğer husus ise dergiye yapılan atıf sayısıdır. Sosyal Güvenlik alanında büyük bir boşluğu dolduran Sosyal Güvenlik Dergisi’nin atıf sayısı dağılımı Grafik 9'da verilmiştir. 
Sosyal Güvenlik Dergisi’nde Yayımlanan Makalelerin Bibliyometrik Analizi

Grafik 9. Sosyal Güvenlik Dergisi'ne Yıllar Ittibariyle Atıf Sayısı Dă̆ılımı

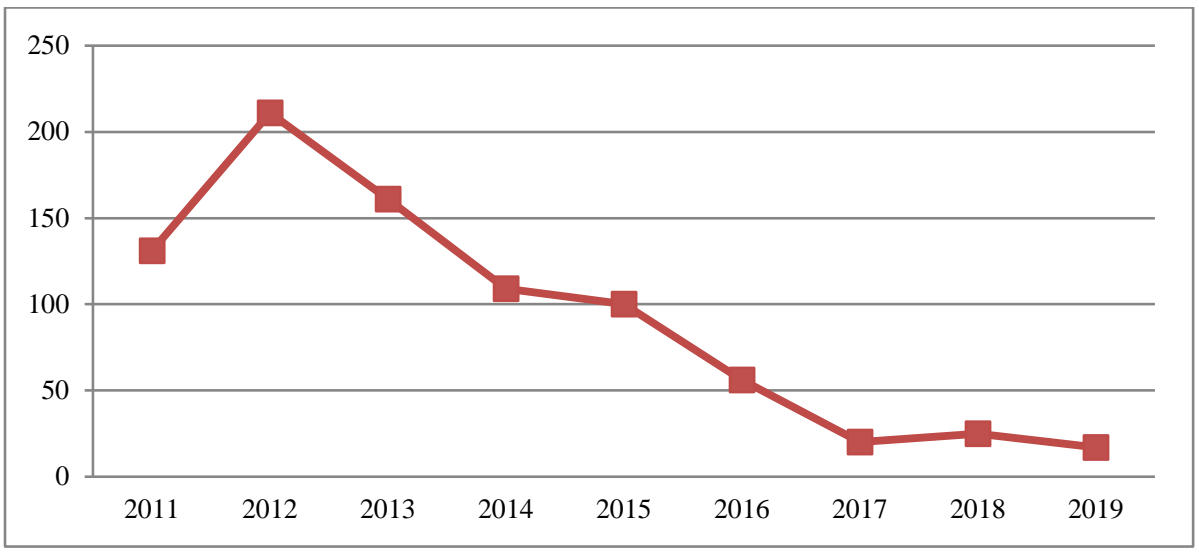

Grafik 9'a göre, 2011 - 2019 yılları arasında dergiye toplam 830* atıf yapılmıştır. Dergi 2011 yılında 131, 2012 yılında 211, 2013 yılında 161. 2014 yılında 109, 2015 yılında 100, 2016 yılında 56, 2017 yılında 20, 2018 yılında 25, 2019 yılında 17 atıf almıştır.

Öz atıf, doğal ve kabul edilebilir bulunmakla birlikte yazarın veya yazarların kendi çalışmalarına yaptığı atıf durumudur. Yazarlar, kendi bilimsel otoritesini kurmak veya önceki çalışmalarını ön plana çıkarmak eğilimindedirler (Aksnes, 2003: 235). Sosyal Güvenlik Dergisi'nde yıllar itibariyle öz atıf sayıları Grafik 10'da verilmiştir.

Grafik 10. Sosyal Güvenlik Dergisi’nde Yıllar İtibariyle Yapılan Öz Atıf Sayısı Dağıllımı

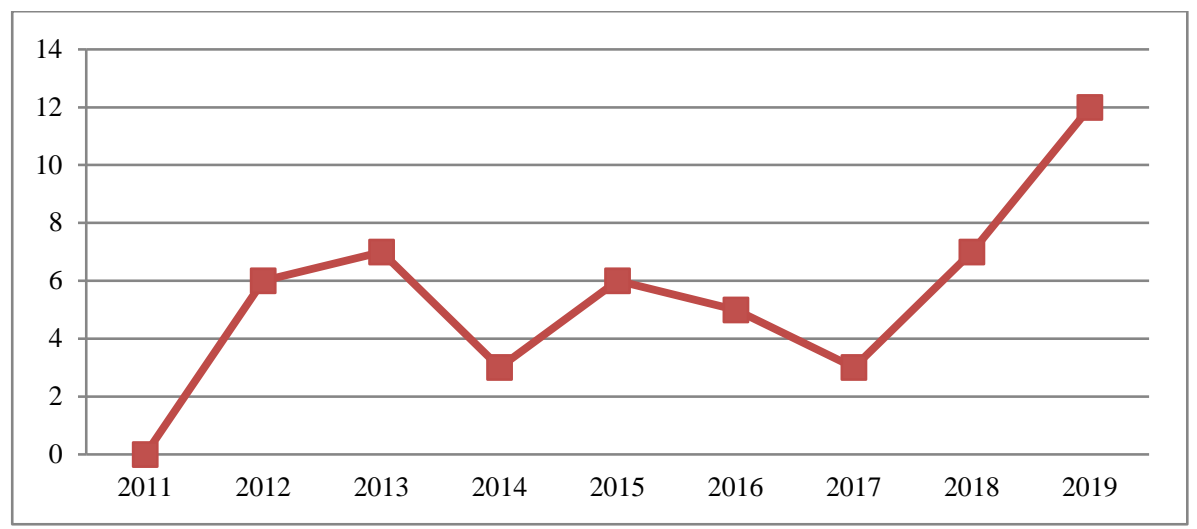

Grafik 10 incelendiğinde toplam 49 öz atıf yapıldı̆̆ı görülmektedir. 2011 yılında 0, 2012 y1lında 6, 2013 yılında 7, 2014 yılında 3, 2015 yılında 6, 2016 yılında 5, 2017 yılında 3, 2018 yılında 7 ve 2019 yılında 12 öz atıf yapılmıştır.

Dergide yayımlanan 138 makalede toplam 584 adet anahtar sözcük kullanılmıştır. Makale başına düşen ortalama anahtar sözcük sayısı 4'tür. Tablo 8'de 3 ve daha fazla kullanılan anahtar sözcük sayıları verilmiştir.

\footnotetext{
*Atıf sayıları, 01.03.2020 tarihi itibariyle Google Akademik’te manuel şekilde sayılarak bulunmuştur.
} 
Tablo 8. Anahtar Sözcüklerde Geçen En fazla Kelime Sayıları

\begin{tabular}{lc} 
Anahtar Kelime & Sayı \\
\hline Türkiye & 15 \\
\hline Sosyal Güvenlik & 11 \\
\hline Sosyal Politika & 8 \\
\hline Yoksulluk & 7 \\
\hline İstihdam & 6 \\
\hline Kayıtıșı İstihdam & 6 \\
\hline İşsizlik & 5 \\
\hline Genel Sağlık Sigortası & 5 \\
\hline Ekonomik Büyüme & 4 \\
\hline İş Sağlığı ve Güvenliği & 4 \\
\hline Refah Devleti & 4 \\
\hline Sosyal Yardım & 4 \\
\hline Aktif İş Gücü Piyasası Politikaları & 3 \\
\hline Emeklilik & 3 \\
\hline İş gücü Piyasası & 3 \\
\hline İş Kazası & 3 \\
\hline Kadın İstihdamı & 3 \\
\hline Performans & 3 \\
\hline Reklam & 3 \\
\hline Sosyal Haklar & 3 \\
\hline Sosyal Koruma & 3 \\
\hline
\end{tabular}

Tablo incelendiğinde en fazla yer alan anahtar sözcük 15 adet ile Türkiye'dir. Bu anahtar sözcüğü takiben sosyal güvenlik (11), sosyal politika (8), yoksulluk (7), istihdam (6), kayıt dışı istihdam (5), işsizlik (5) ve genel sağlık sigortası (5) gelmektedir. Burada dikkat edilmesi gereken husus yukarıda bulunan anahtar kelimelerin eş anlamlıları, ek almış hali ya da yakın sözcükler dikkate alınmamış olmasıdır. Ancak, sağlık alanında yazılmış fazla makale olmasına rağmen sağlık finansmanı, sağlık göstergeleri, sağlık sistemleri gibi farklı kelimelerle anahtar sözcük oluşturulduğu için bu durum tabloda yer almamaktadır.

Bununla birlikte, makalelerde kullanılan anahtar sözcükler kullanılarak en sık kullanılan 50 kelime kriteri belirlenerek Nvivo 12 programıyla oluşturulan kelime bulutu aşağıda Şekil 1'de verilmiştir.

Şekil 1. Anahtar Sözcüklere İlişkin Kelime Bulutu

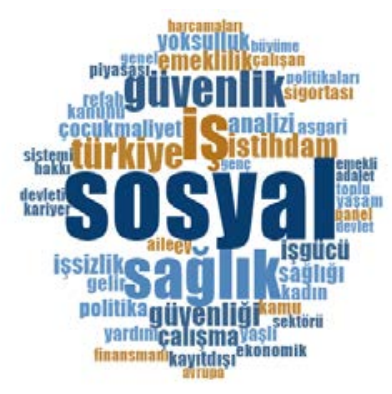

Şekil 1'e bakıldığında makalelerde kullanılan anahtar sözcüklerde en sık kullanılan kelimelerin sosyal, iş, sağlık, güvenlik, Türkiye, istihdam kelimeleri olduğu belirlenmiştir. Kelime bulutu, makalelerde sık işlenen konular ile ilgili bir fikir oluşturulmasına katkı sağlamaktadır. 


\section{SONUÇ}

Bu makalede Sosyal Güvenlik Dergisi'nin bibliyometrik özellikler açısından incelenmesi amaçlanmıştır. Bibliyometrik çalışmalar, farklı disiplin alanlarında gerçekleştirilen çalışmaların niteliklerinin ve niceliklerinin ortaya çıkarılmasına ve yapılacak araştırmalara ışık tutmaktadır. Bu amaçla yapılan çalışmada Sosyal Güvenlik Kurumu faaliyetlerine, sosyal güvenlik, sosyal politika ve endüstri ilişkileri alanına katkı sağlamak amacıyla çıkarılan Sosyal Güvenlik Dergisi'nin bibliyometrik analizi yapılmıştır. Derginin yayın hayatına başladığı yıl olan 2011 ile 2019 yılları arasında toplamda 138 makale yayımlandığı görülmüştür. Yayımlanan makale sayısında son yıllarda artış olmuştur. Sosyal güvenliğin konu olarak daha çok gündeme gelmesi ve tartışılır olması, akademik teşvikler, akademisyenlerin atanma kriterleri ve lisansüstü öğrencilerin tez teslim şartındaki makale yayımlama zorunluluğu gibi nedenlerin bu artışta etkili olduğu söylenebilir.

Yayımlanan makaleler değerlendirildiğinde bireysel çalışmaların yanı sıra çok yazarlılık durumları da dikkati çekmektedir. Bu bağlamda iki yazarlı, üç yazarlı ve dört yazarlı makaleler kendini göstermektedir. Yıllar itibariyle bakıldığında son dönemlerde çok yazarlılık durumunda artış olmuştur. Makaleleri yayımlanan kişilerin unvan durumuna bakıldığında ise ilk sırayı Prof. Dr. almaktadır. Bunu sırasıyla Dr. Öğretim Üyesi, Doç. Dr. ve Araştırma Görevlisi unvanları takip etmişstir.

Dergiye en fazla makale gönderen kurumlar sırasıyla Hacettepe Üniversitesi (13), Ankara Üniversitesi (12) ve Gazi Üniversitesi'dir (12). Dergide yayımlanan makalelerin \% 84’ü üniversiteler, \% 16'sı üniversite dışı kurumlar tarafından gönderilmiştir. Sosyal Güvenlik Kurumu ve ilgili Bakanlık sosyal güvenlik ile iç içe kurumlar olmaları nedeniyle 12 makale ile dergiye katkı yapan kurumların ilk sıralarında yer almaktadır. Dergide makalesi yayımlanan yazarların bulundukları üniversitelerde bağlı oldukları fakülteler incelendiğinde; İktisadi ve İdari Bilimler Fakültesi'nden 70 makale, İktisat Fakültesi'nden 12, Hukuk Fakültesi'nden 11 makale yayımlanmıştır. Makalelerin ortalama sayfa sayısı 24'tür. En çok yazılan makale sayfa sayısı aralığı 21-30 aralığıdır.

Makalelerde başvurulan kaynak türünü \% 53 yerli kaynak, \% 47 yabancı kaynak oluşturmaktadır. Yerli ve yabancı kaynaklarda başvurulan kaynak türlerinin \% 27'sini kitap, \% 42'sini dergi, \% 31'ini diğer kaynaklar oluşturmaktadır. Makalelerin yayım dili incelendiğinde \% 92'sinin Türkçe, \% 8'inin ise İngilizce yazıldığ 1 görülmektedir. Açıç̧ası makalelerin hepsinde İngilizce başlık ve özet yer alsa da uluslararası bir dergi de İngilizce makale sayısının artması yabancı literatür tarafından daha çok atıf almasına katkı sağlayacaktır. Makalelerde toplam 584 anahtar kelime kullanılmış olup makale başına düşen ortalama anahtar kelime sayısı 4'tür. En fazla kullanılan anahtar kelimeler ise sirasıyla Türkiye, sosyal güvenlik, sosyal politika, yoksulluk olarak dikkati çekmektedir.

\section{Kaynakça}

Aksnes, D. W. (2003). A Macro Study of SelfCitation. Scientometrics. 56(2). 235-246.

Al, U. ve Coştur, R. (2007). Türk Psikoloji Dergisi'nin Bibliyometrik Profili. Türk Kütüphaneciliği. 21(2). 142-163.

Al, U. ve Tonta, Y. (2004). Atıf Analizi: Hacettepe Üniversitesi Kütüphanecilik Bölümü Tezlerinde Atıf Yapılan Kaynaklar. Bilgi Dünyası. 5(1). 19-47.
Bellis, Nicole De (2009). Bibliometrics and Citation Analysis From teh Science Citation Index to Cybermetrics. The Scraecrow Press. Inc.

Birinci, H, G. (2008). Turkish Journal of Chemistry'nin Bibliyometrik Analizi. Bilgi Dünyast. 9(2). 348-369.

Cansun, Ş. ve Arık, E. (2019). Türkiye Adresli Siyaset Bilimi Yayınlarının Bibliyometrik Analizi. Ankara Üniversitesi SBF Dergisi. 74(3). 853-874. 
Casey, Debra L. and G. Steven McMillan. (2008). Identifying the Invisible Colleges of the Industrial \& Labor Relations Review: A Bibliometric Approach. ILR Review. 62(1). 126-132.

Casey, Debra L. and G. Steven McMillan. (2019). Employee Voice and Silence: A Bibliometric Analysis of The Literature. International Journal of Bibliometrics in Business and Management (IJBBM). 1(3).

Çokişler, E. (2019). Uluslararası İlişkiler Dergisinin Bibliyometrik Analizi. (2004-2017). Uluslararası İlişkiler. 16(64). 9-56. doi: 10.33458/uidergisi.652899.

Doucouliagos, Hristos., Richard B. Freeman and Patrice Laroche. (2017). A Bibliometric Analysis of What Do Unions Do? The Economics of Trade Unions A Study of A Research Field and Its Findings. Routhledge. London and New York.

Fejes, A. and Nylander, E. (2014). The Anglophone International(e): A Bibliometrical Analysis of three Adult Education Journals. 2005-2012. Adult Education Quarterly. doi: 10.1177/0741713614528025.

Garcia, Jose Alvarez., Amador Duran-Sanches, Marta Peris-Ortiz, and Maria De La Cruz del Rio-Rama. (2020). Public Pension Systems: Bibliometric Study of Academic Publication an Scientific Journals. Marta Peris-Ortiz. José Álvarez-García. Inmaculada DomínguezFabián. Pierre Devolder Economic Challenges of Pension Systems: A Sustainability and International Management Perspective. Springer London.

Ho, Y-S. (2014). Classic Articles on Social Work Field in Social Science Citation Index: A Bibliometric Analysis. Scientometrics. 98. 137155.

Hotamışl1, M. ve Erem, I. (2014). Muhasebe ve Finansman Dergisi'nde Yayınlanan Makalelerin Bibliyometrik Analizi. Muhasebe ve Finansman Dergisi. Temmuz.

Hussain A., Fatima N. and Kumar, D. (2011). Bibliometric Analysis of The 'Electronic Library’ Journal (2000-2010). Webology. 8(1). 87.

Jacobs, D. (2001). A Bibliometric Study of The Publication Patterns of Scientists in South Africa. 1992-96. With Particular Reference to Status and Funding. Information Research. 6(3). [http://informationr.net/ir/6-3/paper104.html]. (Erişim: 15.04.2020).
Krishnamoorthy, G, Ramakrishnan J. and Devi, S. (2009). Bibliometric Analysis of Literature on Diabetes (1995 - 2004). Annals of Library and Information Studies. 56. 150-155.

Manzano, Esther Salmerón- \& Francisco Manzano-Agugliaro. (2017). Worldwide Scientific Production Indexed by Scopus on Labour Relations. Publications. MDPI. Open Access Journal. 5(4). 1-14.

McMillan, G., \& Casey, D. L. (2010). Paradigm Shifts in Industrial Relations: A Bibliometric and Social Network Approach. In D. Lewin, B. E. Kaufman, \& P. Gollan (Eds.). Advances in Industrial and Labor Relations. 17. 207-25. [https://doi.org/10.1108/S0742-6186(2010)000 0017010].

McMillan, G. Steven and Casey, Debra L. (2007). Research Note: Identifying the Invisible Colleges of the British Journal of Industrial Relations: A Bibliometric and Social Network Approach. British Journal of Industrial Relations. 45(4). 815-828. [https://ssrn.com/ abstract=1028380 or http://dx.doi.org/10.1111/j .1467-8543.2007.00645.x].

Müller, A. M., Ansari, P., Ale Ebrahim, N. and Khoo, S. (2015). Physical Activity and Aging Research: A Bibliometric Analysis. Journal of Aging and Physical. 24(3). 476-483. doi: 10.1123/japa.2015-0188.

Liu, X., Zhang L. and Hong, S. (2011). Global Biodiversity Research During 1900-2009: A Bibliometric Analysis. Biodivers Conserv. 20. 807-826.

Okubo, Y. (1997). Bibliometric Indicators and Analysis of Research Systems: Methods and Examples. OECD Science. Technology and Industry Working Papers. 1997/01.

Özel, Ç. H. ve Kozak, N. (2012). Turizm Pazarlaması Alanının Bibliyometrik Profili (2000-2010) ve Bir Atıf Analizi Çalışması. Türk Kütüphaneciliği. 26(4). 715-733.

Özen, Ş. (2001). Türk Yönetim/Organizasyon Yazınında Yöntem Sorunu: Kongre Bildirileri Üzerine Bir İnceleme. Doğu Akdeniz Üniversitesi Turizm Araştırmaları Dergisi. 1(1). 89-118.

Özgüler, V. (2019). Sosyal Siyaset Konferansları Dergisi ve Uluslararası Çalışma Örgütü (ILO). Journal of Social Policy Conferences. (77). 235-285. doi: 10.26650/jspc.2019.77.0013. 
Pritchard, A. (1969). Statistical Bibliography Or Bibliometrics? Journal of Documentation. 25. 348-349.

Ruhanen, L., Weiler, B., Moyle, BD. and McLennan, CJ. (2015). Trends and Patterns in Sustainable Tourism Research: A 25-Year Bibliometric Analysis. Journal of Sustainable Tourism. 23(4). 517-535.

Sosyal Güvenlik Kurumu (2020). Sosyal Güvenlik Dergisi. [http://www.sgk.gov.tr/wps/ portal/sgk/sgd/tr/Ana_sayfa]. (Erişim: 15.04.2020).

Şakar G. D. ve Cerit A. G. (2013). Uluslararası Alan İndekslerinde Türkiye Pazarlama Yazını: Bibliyometrik Analizler ve Nitel Bir Araştırma. Atatürk Üniversitesi İktisadi ve İdari Bilimler Dergisi. 27 (4).

Üsdiken, B. ve Erçek, M. (2009). Türkiye'de İş Dünyası İçin İlk 'İşletme' Dergisi: İşletme İşletme Ekonomisi ve Organizasyon Mecmuası. Yönetim Araştırmaları Dergisi. 9(1). 53-90.

Üsdiken, B. and Wasti, S. A. (2009). Preaching, Teaching and Researching at the Periphery: Academic Management Literature in Turkey. 1970-1999. Organization Studies. 30(10). 10631082.

Valdez-Martínez, E., J Garduño-Espinosa, A Gómez-Delgado, J Dante Amato-Martínez, L Morales-Mori, F Blanco-Favela. O MuñozHernández. (2000). Bibliometric Analysis of Publications by the Mexican Social Security Institute Staff. (Article in Spanish). JulAug;136(4). 319-28.PMID: 10992632. Gac Med Mex. 
